\title{
On the MG Values in Paper-electrophoresis
}

Sir:

We have already reported on the MG values of amino acids in paper-electrophoresis ${ }^{1,2)}$, which were the constants regardless of voltage, current, time of electrophoresis, dropped point and length of filterpaper. Afterwards, mathematical analysis was applied to the migration distance of amino acids and serum proteins under the influence of evaporation from filterpaper and electroosmosis and it was found that the net-initial velocity of migrant $\mathrm{A}(\mathrm{B}, \mathrm{C}, \mathrm{D}, \mathrm{E})$ shown in Fig. $1, V_{0 \mathrm{~A}(\mathrm{~B}, \mathrm{C}, \mathrm{D}, \mathrm{E}) \text {, could }}$ be calculated by the following formula, which was in conformity in a considerable accuracy of $96 \%(92 \% \sim 105 \%)$, with the net-migation velocity in the filterpaper clamped between glass plates ${ }^{3)}$.

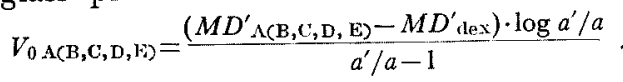

In formula (1), $M D_{A\left(\mathrm{D}, \mathrm{C}^{\prime}, \mathrm{D}, \mathrm{E}\right)}^{\prime}$ shows the ap-

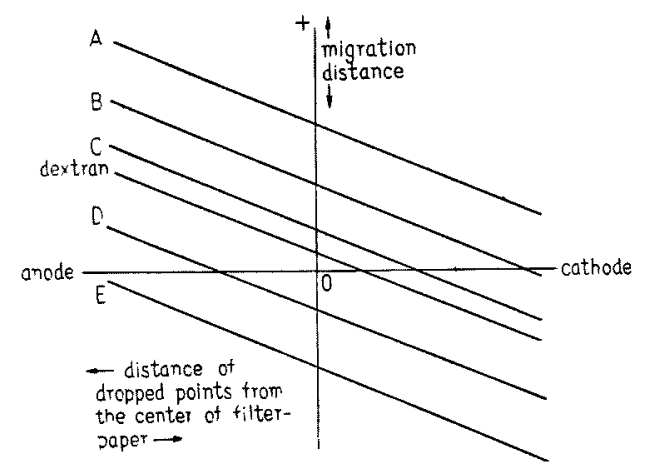

FIG. 1. The Relationships between the Migration Distance of A (B, C, D, E, Dextran) and Dropped Points $^{2)}$ parent migration distance of $\mathrm{A}(\mathrm{B}, \mathrm{C}, \mathrm{D}, \mathrm{E})$ from the original point at the time of $t_{1}$, $M D^{\prime}$ dex the apparent migration distance of dextran at the same time, $a^{\prime} / a$ the decrement ratio of migration velocity of the migrant at the interval of $t_{1}$.

When we take the following ratio as $\mathrm{MG}$ of $\mathrm{B}(\mathrm{C}, \mathrm{D})$, $\mathrm{MG}_{\mathrm{B}(\mathrm{C}, \mathrm{D})}=\frac{\text { migration distance of } \mathrm{B}(\mathrm{C}, \mathrm{D}) \text { from } \mathrm{A}}{\text { migration distance of } \mathrm{E} \text { from } \mathrm{A}}$ then, the $M G$ of $B(C, D)$ is expressed as:

$$
\begin{aligned}
\mathrm{MG}_{\mathrm{B}(\mathrm{C}, \mathrm{D})} & =\frac{M D_{\mathrm{B}(\mathrm{C}, \mathrm{D})}^{\prime}-M D_{\Lambda}^{\prime}}{M D_{\mathrm{E}}^{\prime}-M D_{\Lambda}^{\prime}}=\frac{V_{0 \mathrm{~B}(\mathrm{C}, \mathrm{D})}-V_{0 \Lambda}}{V_{0 \mathrm{~B}}-V_{0 \Lambda}} \\
& =\frac{l / l^{\prime} \cdot m_{\mathrm{B}(\mathrm{C}, \mathrm{D})}-l / l^{\prime} \cdot m_{\Lambda}}{l / l^{\prime} \cdot m_{\mathrm{E}}-l / l^{\prime} \cdot m_{\Lambda}} \\
& =\frac{m_{\mathrm{B}(\mathrm{C}, \mathrm{D})}-m_{\Lambda}}{m_{\mathrm{E}}-m_{\Lambda}} \quad \ldots \ldots \ldots \ldots \ldots \ldots
\end{aligned}
$$

where $m_{A}, m_{\mathrm{B}}, m_{C}, m_{\mathrm{D}}$ and $m_{\mathrm{E}}$ is respectively the mobilities of $\mathrm{A}, \mathrm{B}, \mathrm{G}, \mathrm{D}$ and $\mathrm{E}, l / l^{\prime}$ the correction factor of filterpaper for calculation of mobility of migrant3). From formula (2) it is evident that the MG value in this definition is equal to the ratio of differences of mobilities, which is constant regardless of voltage, current, time of electrophoresis, dropped point and length of filterpaper. Table I shows the MG values of amino acids and serum proteins, each in accordance with the following definition, which were obtained both by actual measurement under the influence of evaporation from paper surface and by calculation of substituting $l / l^{\prime} \cdot \mathrm{m} \mathrm{cm}^{2} \cdot$ volt $^{-i}$. $\mathrm{sec}^{-1}$ in equation (2), where $l / l^{\prime} \cdot m \mathrm{~cm}^{2} \cdot$ volt $^{-1}$. $\sec ^{-1}$ was acquired by a method of clamping filterpaper between glass plates ${ }^{3)}$.

$$
\begin{aligned}
M G & =\frac{\text { migration distance of other serum proteins from } \gamma \text {-globuline }}{\text { migration distance of serum albumine from } \gamma \text {-globuline }} \\
M G & =\frac{\text { migration distance of other amino acids from arginine }}{\text { migration distance of aspartic acid from arginine }}
\end{aligned}
$$

1) K. Sakamoto, K. Tateoka, This Bulletin, 20, 98 (1956). 2) K. Sakamoto, K. Tateoka, J. Agr. Cben. Soc. Jap, 30, 463 (1956).

We wish to express our sincere gratitude 
TABLE I

The Mg Values of Amino acids observed in Several pH of Phosphate Buffers (A) aNd Serum Proteins in a Barbital Buffer of pH 8.5 (B)

F : found values

C: calculated values from $l / l^{\prime} \cdot m$

(A)

\begin{tabular}{|c|c|c|}
\hline $\mathrm{pH}^{\text {Amino acid }}$ & $\begin{array}{l}\text { Aspartic } \\
\text { acid }\end{array}$ & $\begin{array}{l}\text { Glutamic } \\
\text { acid }\end{array}$ \\
\hline $8.3\left\{\begin{array}{l}\mathbf{F} \\
\mathrm{C}\end{array}\right.$ & $\begin{array}{l}1.00 \\
1.00\end{array}$ & $\begin{array}{l}0.92 \pm 0.03 \\
0.89\end{array}$ \\
\hline $7.3\left\{\begin{array}{l}\mathbf{F} \\
\mathrm{C}\end{array}\right.$ & $\begin{array}{l}1.00 \\
1.00\end{array}$ & $\begin{array}{l}0.87 \pm 0.03 \\
0.85\end{array}$ \\
\hline $6.4\left\{\begin{array}{l}F \\
C\end{array}\right.$ & $\begin{array}{l}1.00 \\
1.00\end{array}$ & $\begin{array}{l}0.85 \pm 0.04 \\
0.82\end{array}$ \\
\hline $5.5\left\{\begin{array}{l}F \\
\mathrm{C}\end{array}\right.$ & $\begin{array}{l}1.00 \\
1.00\end{array}$ & $\begin{array}{l}0.82 \pm 0.03 \\
0.81\end{array}$ \\
\hline $4.5\left\{\begin{array}{l}F \\
C\end{array}\right.$ & $\begin{array}{l}1.00 \\
1.00\end{array}$ & $\begin{array}{l}0.78 \pm 0.04 \\
0.79\end{array}$ \\
\hline $\mathrm{MG}\left\{\begin{array}{l}\mathrm{F} \\
\mathrm{C}\end{array}\right.$ & $\begin{array}{c}\text { Albumine } \\
1.00 \\
1.00\end{array}$ & $\begin{array}{l}\alpha_{1} \text {-Globulin } \\
0.81 \pm 0.03 \\
0.82\end{array}$ \\
\hline
\end{tabular}

to Prof. Y. Öshima and Ass. Prof. Funatsu of Kyushu University for their kind guidance.

Kiyoshi Sakamoto

Kinuko SAIto

\begin{tabular}{|c|c|c|}
\hline $\begin{array}{l}\text { Neutral amino } \\
\text { acid }\end{array}$ & Histidine & $\begin{array}{c}\text { Arginine } \\
\text { Lysine }\end{array}$ \\
\hline $0.34 \pm 0.03$ & $\begin{array}{l}0.30 \pm 0.02 \\
0.28\end{array}$ & $\begin{array}{l}0 \\
0\end{array}$ \\
\hline $0.38 \pm 0.03$ & $\begin{array}{l}0.24 \pm 0.03 \\
0.27\end{array}$ & $\begin{array}{l}0 \\
0\end{array}$ \\
\hline $0.45 \pm 0.03$ & $\begin{array}{l}0.18 \pm 0.02 \\
0.17\end{array}$ & $\begin{array}{l}0 \\
0\end{array}$ \\
\hline $0.50 \pm 0.02$ & $\begin{array}{l}0.09 \pm 0.03 \\
0.08\end{array}$ & $\begin{array}{l}0 \\
0\end{array}$ \\
\hline $0.54 \pm 0.03$ & $\begin{array}{l}0.04 \pm 0.02 \\
0.02\end{array}$ & $\begin{array}{l}0 \\
0\end{array}$ \\
\hline
\end{tabular}

(B)

$\begin{array}{ccc}\alpha_{2} \text {-Globuline } & \beta \text {-Globuline } & \gamma \text {-Globuline } \\ 0.59 \pm 0.04 & 0.35 \pm 0.03 & 0 \\ 0.56 & 0.35 & 0\end{array}$

Laboratory of Nutrition, Faculty of Junior Course, Kagoshima Prefectural University, Ishiki-cho, Kagoshima, Japan Received June 17, 1957 